Results and Discussion

\section{Inheritance of leaf variegation In Vitis species}

\section{B. I. Relsch and J. P. Watson}

- ABSTRACT: Chlorophyll varlegation in Vitts species was examined in $F_{1}$ and $S_{1}$ populations. A single recossive gene is proposed to account for the occurrence of 25 percent varlegated seedlings in both $F_{1}$ and $S_{1}$ populations. Varlegation was not lethal and might be useful In wine grape breeding (if assoclated with Inactlve polyphenol oxidase)

$\omega$ and for its omamental value. This tralt is one of very fow seedling traits under monogenic control that might be useful in genetic studles of grapes.

LEAF VARIEGATION in Vitis has been described - among the progeny of Aramon, an ancient Eu. ropean grape ( $V$. vinifera) cultivar ${ }^{5}$. A single recessive gene was reported to cause green and white variegation among selfed progeny of Aramon. However, such variegation was expressed only among plants grown at $20^{\circ} \mathrm{C}$, not at $35^{\circ} \mathrm{C}^{5}$. Variegation also was described in a sport

1 of cv. Sultana, but inheritance was not studied'. We have observed that, following severe cold damage to dormant buds, small variegated shoots are a common vineyard occurrence.

Well-defined mutants identifiable at an early stage of growth are of importance in genetic studies of plants. De Lattin ${ }^{3}$ listed 53 genes identified in Vitis prior to 1957. Of these, four concerned traits identifiable among seedlings. No further seedling traits have since been reported 4 .

- Variegated leaves appeared in seedling grapevine populations planted in 1982 and were studied to identify the genetic basis for their occurrence.

\section{Materials and Methods}

Crosses and selfs among hybrid stocks (see - Figure 1) and $V$. vinifera grape cultivars (Riesling and Chardonnay) were made in 1981 and 1982 using standard techniques ${ }^{4}$. Seed were stratified for 3 months at $1-2^{\circ} \mathrm{C}$ and planted in Cornell-Mix ${ }^{2}$ medium in a greenhouse in midMarch of 1982 and 1983. Approximately 4 weeks after planting, seedlings showing true leaves were classified as either variegated (green and white)

* or normal (entirely green). The available data were subjected to chi-square analysis to determine goodness-of-fit to the Mendelian monohybrid ratio. In June 1982 and 1983, seedlings were transplanted to a field nursery and observed for survival and expression of variegation.

The authors are affiliated with the Department of Horticultural Sciences, New York State Agricultural Experiment Station, Cornell University, Geneva, New York 14456. They wish to thank Dr. R. Pool for valuable discussions.

0 1984, American Genetic Association.
Most of the variegated seedlings showed a green and white pattern of variegation. A few variegated seedlings had patches of pinkishpurple and patches of green tissue in true leaves and occasionally in the cotyledons. The pinkish-purple color eventually bleached out, leaving white tissue in its place. Leaves on variegated seedlings ranged from almost entirely green to entirely white. Classification at the cotyledon to first true leaf stage was inaccurate; 10 days later many seedlings classified earlier as normal showed leaf variegation. Data collected from seedlings showing 2-4 true leaves were subsequently analyzed and the results are presented here. The symbol var is proposed for the mutant causing green and white leaf variegation.

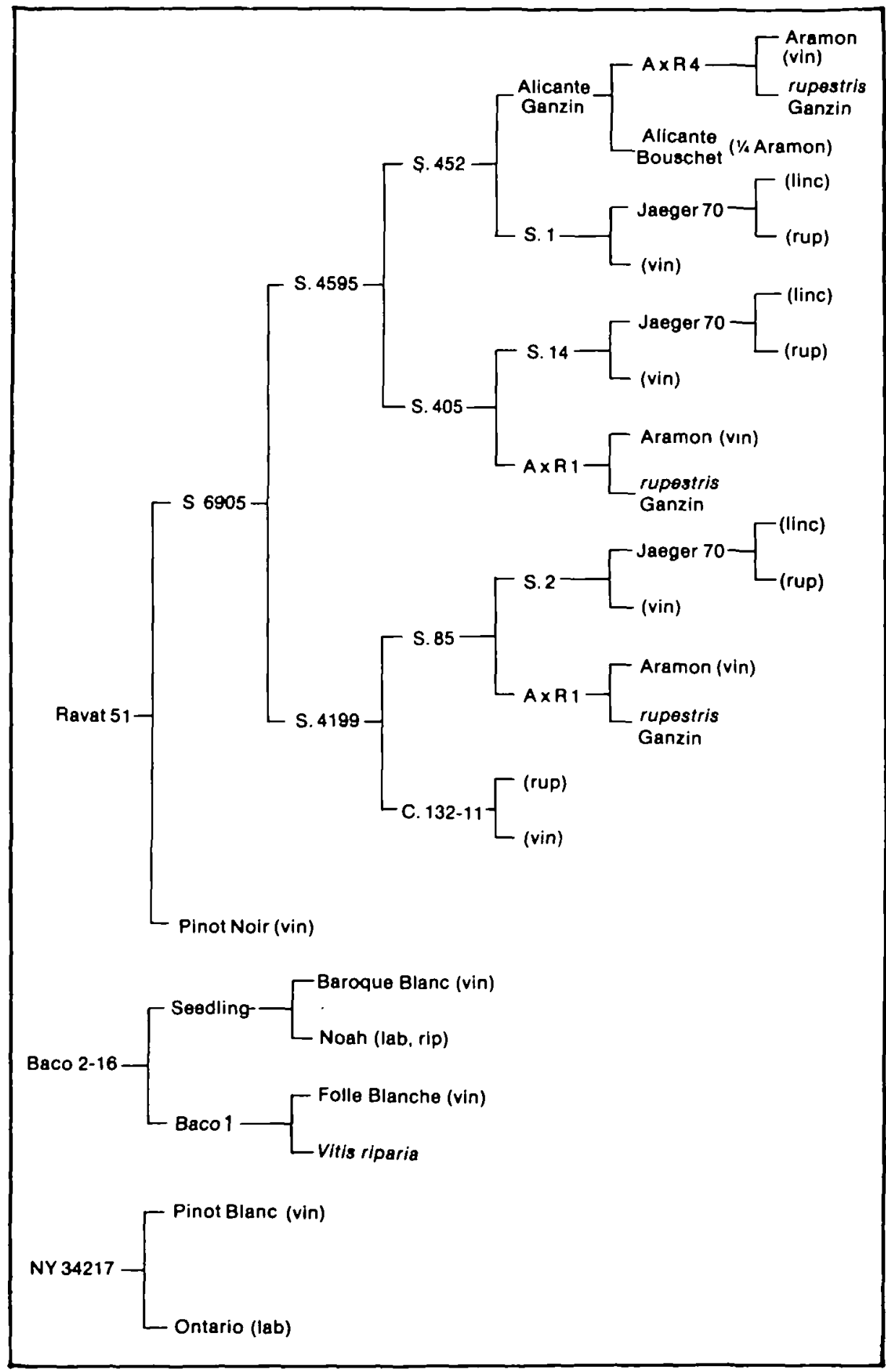

FIGURE 1 Pedigree of hybrid stocks used in the study of variegation in Vitis. Abbreviations for species: vinvinifera; lab-labrusca; rip-riparia; linc-lincecumil; rup-rupestris. 
Variegated plants from crosses made in 1981 continued to express the trait in tissues produced in 1982, 1983, and 1984 (Figure 2). Expression within each plant was irregular; some shoots were entirely green, others were intensely variegated. Only a few seedlings classed as normal exhibited variegation in the field. These individuals had apparently been misclassified at the seedling stage. Following two seasons in the field, 78 of 149 green plants in two $F_{1}$ populations survived, as did 15 of 48 variegated plants. Apparently, variegation was not a lethal trait, although it appears to decrease plant survjval. Surviving variegated plants appeared to be as vigorous as their normal sibling counterparts.

It is proposed that NY 34217, Riesling, Chardonnay, Ravat 51, and Baco 2-16 are heterozygous ( + var) for the variegated trait. Hence, hybrid and selfed progeny within this group should have 25 percent variegated seedlings. Only one of 10 populations (Table I) analyzed using the chi-square test did not fit this hypothesis. In that atypical case, a self-pollinated population from Riesling included only 16 percent variegated seedlings. Misclassification at an early growth stage and possible temperature effects on variegation ${ }^{5}$ would help to explain a deficiency of seedlings classed as variegated.

Albinos occur at very low frequencies $(<0.5$ percent) in many grape seedling populations. They occurred at a frequency of 16 percent among self-pollinated seedlings of Ravat 51 (Table I) and were considered in the statistical analysis to be an extreme form of expression for the variegated trait. Albinism has been considered to be an extension of leaf variegation traits in other studies as well?.

In 14 progeny having one parent in common with those segregating for leaf variegation, all observed seedlings were green (Table II). The cross involved would represent $++X+$ var, with the expectation of producing all green seodlings. Self-pollinated progeny of three putative ++ genotypes also produced only green seedlings (Table II).

Studies on the grape cultivar Aramon suggested monogenic inheritance of a variegated trait ${ }^{5}$. Since Ravat 51 derives approximately 9.0 percent of its genetic makeup from Aramon

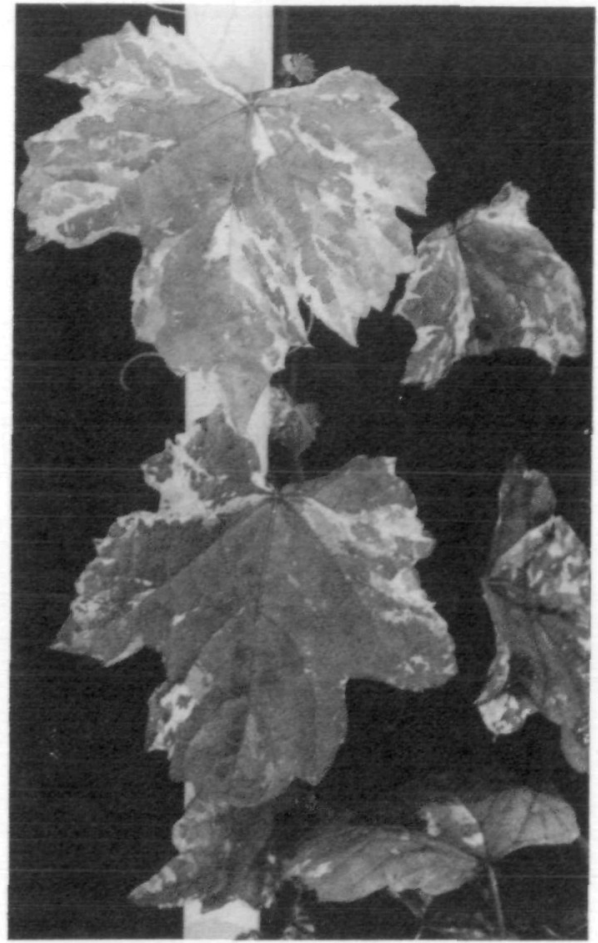

FIGURE 2 Leaf variegation in a 31-year-old Vitis seedling.

through four independent sources (Figure 1) it is possible that the gene investigated is identical to that found in Aramon and now identified in the four other grape stocks reported here.

Grapevines grown in pot culture from cuttings are being developed as an attractive florist crop $^{6,9}$. A variegated stock might have additional ornamental value.

The mutant trait presently under study also may be of some importance in the production of new grape cultivars that resist oxidation in their wine. Grapevine variegation has been found in association with Bruce's sport, a variant of the Sultana grape, which was characterized by a decreased tendency of the fruit to brown while

Table I. Segregation data and chi-square tests for green and variegated (var) leaf traits among Vitis seedlings

\begin{tabular}{|c|c|c|c|c|c|}
\hline \multirow[b]{2}{*}{ Cross } & \multicolumn{3}{|c|}{ No. seedlings } & \multirow[b]{2}{*}{$\chi^{2}(3: 1)$} & \multirow[b]{2}{*}{$P$} \\
\hline & total & green & variegated & & \\
\hline \multicolumn{6}{|l|}{$F_{1}$ populations } \\
\hline NY $34217 \times$ Riesling & 126 & 86 & 40 & 3.06 & $0.05-0.20$ \\
\hline NY $34217 \times$ Baco 2-16 & 220 & 164 & 56 & 0.02 & $0.80-0.95$ \\
\hline NY $34217 \times$ Ravat 51 & 62 & 52 & 10 & 2.60 & $0.05-0.20$ \\
\hline Ravat $51 \times$ Riesling & 119 & 96 & 23 & 2.07 & $0.05-0.20$ \\
\hline Ravat $51 \times$ Chardonnay & 325 & 246 & 79 & 0.09 & $0.50-0.80$ \\
\hline \multicolumn{6}{|l|}{$S_{1}$ populations } \\
\hline NY 34217 selfed & 14 & 9 & 5 & 0.86 & $0.20-0.50$ \\
\hline Ravat 51 selfed & 216 & 163 & $19 t$ & 0.02 & $0.80-0.95$ \\
\hline Riesling selfed & 199 & 168 & 31 & 9.47 & $<0.01 *$ \\
\hline Chardonnay selfed & 42 & 33 & 9 & 0.29 & $0.50-0.80$ \\
\hline Baco 2-16 selfed & 270 & 205 & 65 & 0.12 & $0.50-0.80$ \\
\hline
\end{tabular}

- Does not fit expected ratio

+34 albino drying $^{1}$. A form of polyphenol oxidase characterized by greatly reduced activity was responsible for resistance to oxidation of grape phenolic compounds sensitive to browning 8 . This altered form of polyphenol oxidase may be a valuable . trait in retarding oxidation in commercial wines. The genetic relationship between variegation and altered forms of polyphenol oxidase has not yet been elucidated. However, if the variegated trait presently under study is identical to that found in Bruce's sport and is associated with an inactive form of polyphenol oxidase, it may be a useful trait to manipulate for the benefit of a wine grape breeding program.

\section{References}

I. ANTClifF, A. J. and W. J. WEBSTER. Bruce's sport-a mutant of the sultana. Australian J. Expt. Agr. Anim. Husb. 2:97-100. 1962.

2. BOODLEY, J. W. and R. SheldRAKE, JR. Cornell : peatlite mixes for commercial plant growing. Inf. Bul. 43. Cornell Coop. Extension, Ithaca, NY. 1982.

3. DE LAtTIN, G. Zur Genetik der Reben. Bisherige Ergebnisse der Faktoranalyse bei der Gattung Vitis. Vitis 1:1-8. 1957

4. EINSET, J. and C. PRATt. Grapes. In Advances in . Fruit Breeding. J. Janick and J. N. Moore, Eds. Purdue Univ. Press, Lafayette, IN. p. 130-153. 1975. -

5. GALZY, R. and P. GALZY. Action de la temperature sur la panachure blanche de la vigne. Le Progres Agricole et Viticole 162:271-280. 1964.

6. JANICK, J. Production of fruiting grapevines for pot culturc. HortScience 18:56-57. 1983.

7. ORAKwUE, F, C. and L. V. CROWDER. Inheritance of variegation in Brassica campestris. L. J. Hered. 74:65-67. 1983.

8. RADLER, F. The prevention of browning during drying by the cold dipping treatment of sultana grapes. J. Sci. Food Agric. 15:864-869. 1964.

9. RoBitaille, H. A. and J. JANICK. Rapid production of small fruiting grapevines from softwood cuttings. HortScience 14:161. 1979.

Table I. Other crosses and selfs related to segregating populations in which no variegated seedlings were observed

\begin{tabular}{lc}
\hline \multicolumn{1}{c}{ Cross } & $\begin{array}{c}\text { No. seedlings } \\
\text { observed }\end{array}$ \\
\hline NY 65.444.4 X Riesling & 93 \\
NY 65.533.13 X Riesling & 37 \\
GW 5 × Riesling & 51 \\
Horizon X Riesling & 5 \\
Cayuga White X Riesling & 186 \\
S. 13047 X Riesling & 75 \\
J.S. 23-416 X Riesling & 105 \\
J.S. 26-627 X Riesling & 141 \\
NY 65.444.4 X Chardonnay & 49 \\
S. 10173 X Chardonnay & 92 \\
Ill. 172-7 X Chardonnay & 47 \\
Horizon X Baco 2-16 & 32 \\
NY 65.533.13 X Ravat 51 & 22 \\
Cayuga White X Ravat 51 & 39 \\
J.S. 23-416 selfed & 54 \\
NY 65.444.4 selfed & 200 \\
Horizon selfed & 54 \\
\hline
\end{tabular}

- Abbreviations used: NY = New York; GW = Geneva White; S. = Seibel; J.S. = Joannes-Seyve; IIl. - Illinois 